\title{
Comparison of the sedative effects of morphine, meperidine or fentanyl, in combination with acepromazine, in dogs
}

\author{
Comapração dos efeitos sedativos da morfina, meperidina ou fentanil, associados à acepromazina, \\ em cães
}

\author{
Viviane Horta Gomes ${ }^{\mathrm{I}}$ Eduardo Raposo Monteiro ${ }^{\mathrm{I}^{*}}$ Raquel Sartori Dias $^{\mathrm{I}}$ Renato Leão Sá de Oliveira ${ }^{\mathrm{I}}$ \\ Marta Fernanda Albuquerque da Silva ${ }^{\mathrm{I}}$ Karina Coelho ${ }^{\text {II }}$
}

\section{ABSTRACT}

This study aimed to compare the sedative effects of morphine, meperidine and fentanyl, in combination with acepromazine (ACP) and their effects on physiologic values in dogs. Six healthy beagle dogs were randomly assigned to four treatments with 7-day washout intervals. In three treatments, ACP $\left(0.05 \mathrm{mg} \mathrm{kg}^{-1}\right)$ was administered and 20 minutes later, the dogs received administration of $0.5 \mathrm{mg} \mathrm{kg}^{-1}$ of morphine (ACPMOR), $5 \mathrm{mg} \mathrm{kg}^{-1}$ of meperidine (ACPMEP) or $5 \mu \mathrm{g} \mathrm{kg}^{-1}$ of fentanyl (ACPFEN). In treatment ACP ${ }_{H D} M O R, 0.1 \mathrm{mg} \mathrm{kg}^{-1}$ of ACP was administered in combination with $0.5 \mathrm{mg} \mathrm{kg}^{-1}$ of morphine. All drugs were administered intravenously. Sedation scores were evaluated by a numeric descriptive scale (NDS: 0-3) and a simple numeric scale (SNS: 0-10). All variables were evaluated for 120 minutes. The administration of ACP caused mild to moderate sedation. Sedation was improved in all treatments after opioid administration, but significant differences were detected only in ACPMOR and ACP ${ }_{H D} M O R$. More dogs presented intense sedation $(N D S=3.0)$ after administration of morphine (3/6 and 4/6 dogs in ACPMOR and $A C P_{H D} M O R$ versus $1 / 6$ in other treatments). Duration of sedation was longer in ACPMOR and $A C P_{H D} M O R$. Mild to moderate decreases in blood pressure, respiratory rate and temperature were observed in all treatments but decreased $H R$ was observed only in ACPMOR and $A C P_{H D} M O R$. No significant differences were observed in the aforementioned variables when twice the dose of ACP was used (treatment $\left.A C P_{H D} M O R\right)$. Under the conditions of this study, administration of morphine, in combination with ACP, results in greater and longer sedation than meperidine and fentanyl. Increasing the dose of ACP, in combination with morphine, does not improve the degree of sedation. All combinations used were considered to be safe for healthy dogs.

Key words: sedation, opioids, phenothiazines.

\section{RESUMO}

$O$ presente estudo objetivou comparar o efeito sedativo da morfina, meperidina e fentanil associados à acepromazina (ACP) e seus efeitos sobre as variáveis fisiológicas de cães. Seis cães Beagle hígidos foram aleatoriamente submetidos a quatro tratamentos com intervalo de 7 dias. Em três tratamentos, foi administrada ACP $\left(0,05 \mathrm{mg} \mathrm{kg}^{-1}\right) e$, após 20 minutos, $0,5 \mathrm{mg} \mathrm{kg}^{-1}$ de morfina (ACPMOR), $5 \mathrm{mg} \mathrm{kg}^{-1} \mathrm{de}$ meperidina (ACPMEP) ou $5 \mu \mathrm{g} \mathrm{kg}^{-1}$ de fentanil (ACPFEN). No tratamento $A C P_{D A} M O R$, a dose de $0,1 \mathrm{mg} \mathrm{kg}^{-1}$ de ACP foi associada a $0,5 \mathrm{mg} \mathrm{kg}^{-1}$ de morfina. Todos os fármacos foram administrados pela via IV. Escores de sedação foram avaliados pela escala numérica descritiva (END: 0-3) e escala numérica simples (ENS: 0-10). Todas as variáveis foram avaliadas durante 120 minutos. A administração da ACP causou sedação leve à moderada. A sedação foi intensificada em todos os tratamentos após a administração do opioide, mas diferença significativa foi observada somente em ACPMOR e ACP ${ }_{D A} M O R$. Um número maior de cães apresentou sedação intensa $(E N D=3,0)$ após a administração da morfina (3/6 e 4/6 cães em ACPMOR e ACP ${ }_{D A}$ MOR versus $1 / 6$ nos demais tratamentos). $A$ duração do efeito sedativo foi mais longa em ACPMOR $e$ $A C P_{D A} M O R$. Houve redução leve a moderada na pressão arterial, frequência respiratória e temperatura em todos os tratamentos e redução significativa da frequência cardíaca somente nos tratamentos ACPMOR e ACP ${ }_{D A} M O R$. Não houve diferenças significativas nas variáveis estudadas quando $o$ dobro da dose de ACP foi utilizada (tratamento ACP ${ }_{D A} M O R$ ). Nas condições deste estudo, a administração da morfina, em associação à ACP, resulta em sedação de maior intensidade e duração do que a meperidina e o fentanil. $O$ aumento na dose de ACP, em associação à morfina, não intensifica o grau de sedação. Todas as associações foram consideradas seguras para cães hígidos.

Palavras-chave: sedação, opioides, fenotiazínicos.

Instituto de Veterinária,Universidade Federal Rural do Rio de Janeiro (UFRRJ), Seropédica, RJ, Brasil.

"Programa de Pós-graduação em Ciência Animal, Centro Universitário Vila Velha (UVV), 29102-770, Vila Velha, ES, Brasil.

E-mail: eduardo.raposo@uvv.br. *Autor para correspondência. 


\section{INTRODUCTION}

Phenothiazine derivatives, such as acepromazine (ACP), are widely used in veterinary medicine with the aim to produce sedation in dogs. However, these drugs are devoid of analgesic effects (HALL et al., 2001). Therefore, these drugs are generally administered in combination with opioid analgesics, and this combination has been named neuroleptanalgesia. When phenothiazine-opioid combinations are used, synergism seems to occur and sedation and analgesia appears to be greater with the combination than when each drug is administered alone (SMITH et al., 2001; MONTEIRO et al., 2008; MONTEIRO et al., 2009).

Morphine is the prototype of opioid analgesics. For comparison purposes, its analgesic potency has been considered to be 1 . Although there are opioids with greater potency, no one was found to be as effective as morphine in treating pain (WAGNER, 2002). Morphine is a pure $\mu$ agonist that provides analgesia for approximately 4 hours (PASCOE, 2000). The main adverse effects after its administration are respiratory depression, decrease in heart rate and vomiting (PASCOE, 2000).

Meperidine is a synthetic opioid which acts as a pure agonist at $\mu$ receptors. This drug was shown to have one tenth the potency of morphine and to provide moderate analgesia, in comparison to morphine, lasting 1 to 2 hours. It has been reported that meperidine causes similar side effects to morphine (PASCOE, 2000).

Fentanyl is a potent synthetic opioid with strong agonist properties at $\mu$ receptors (PASCOE, 2000); this drug was shown to be 100 times more potent than morphine (WAGNER, 2002). Fentanyl is an ultrashort agent which has a rapid onset of action and is used mainly as an infusion to provide a continuous level of analgesia (PASCOE, 2000), but also as part of neuroleptoanalgesic preparations, especially in combination with droperidol (HALL et al., 2001).

It has been reported in the literature that the degree of sedation provided by neuroleptoanalgesic preparations may vary according to the opioid used (MONTEIRO et al., 2009). The present study aimed to compare the sedative effects provided by combinations of ACP with morphine, meperidine or fentanyl, as well as to assess the changes caused by these combinations in physiologic values of dogs. This study also aimed to determine whether there are differences in the degree of sedation provided by different doses of ACP in combination with a single dose of morphine.

\section{MATERIALS AND METHODS}

Six healthy, Beagle dogs (five males and one female), aged 3-4 years and weighing $12.1 \pm 1.1 \mathrm{~kg}$ (mean $\pm \mathrm{SD}$ ) were used in the study. Healthy status of dogs was assessed by physical examination, a complete blood count and serum biochemical analyses. All findings were with reference ranges for dogs.

Food, but not water, was withheld for 12 hours prior to anesthetic procedures. Thirty minutes before the start of the experiment, each dog was allowed to acclimate to a quiet room, with temperature at $25^{\circ} \mathrm{C}$. The dogs were instrumented with a Doppler ${ }^{\mathrm{a}}$ ultrasonic flow probe placed on the palmar digital artery, with a sphygmomanometer and cuff placed above the carpus, to allow determination of systolic arterial pressure (SAP). Cuff width was $40-50 \%$ of limb circumference. Heart rate (HR) was determined with a stethoscope, respiratory rate $\left(f_{\mathrm{R}}\right)$ was measured by observing thoracic excursions and rectal temperature was determined using a digital thermometer.

The degree of sedation was assessed using a numeric descriptive scale (NDS) and a simple numerical scale (SNS). The NDS (MONTEIRO et al., 2009) consisted of a scale ranging from 0 to 3 , with 0 : no sedation; 1: mild sedation (less alert, but still active); 2: moderate sedation (drowsy, recumbent but can walk); and 3: intense sedation (very drowsy, unable to walk). The SNS consisted of a scale ranging from 0 to 10 where 0 represents no sedation and 10 represents the most sedation possible. To assess the degree of sedation, the dog was observed initially undisturbed and unrestrained on a table. Subsequently, with the dog in lateral recumbency, SAP, $\mathrm{HR}, f_{\mathrm{R}}$ and temperature were measured. Finally, the dog was placed on the floor and the assessor encouraged it and observed if the dog was able to walk. A single observer, who was unaware of the treatment administered, was responsible for assessing the degree of sedation and physiologic values on all occasions.

The animals were randomly assigned to receive four treatments, on different occasions, with 1week washout intervals. In three treatments, the dogs received acepromazine ${ }^{\mathrm{b}}\left(0.05 \mathrm{mg} \mathrm{kg}^{-1}\right)$ and 20 minutes later, one of three opioids was administered: $0.5 \mathrm{mg} \mathrm{kg}^{-1}$ of morphine ${ }^{\mathrm{c}}$ (ACPMOR); $5 \mathrm{mg} \mathrm{kg}^{-1}$ of meperidine ${ }^{\mathrm{d}}$ (ACPMEP); and $5 \mu \mathrm{g} \mathrm{kg}^{-1}$ of fentanyl ${ }^{e}$ (ACPFEN). In another group ( $\mathrm{ACP} \mathrm{HD}_{\mathrm{HDOR}}$ ) the dogs received $0.1 \mathrm{mg}$ $\mathrm{kg}^{-1}$ of ACP and after 20 minutes, $0.5 \mathrm{mg} \mathrm{kg}^{-1}$ of morphine.

Following determination of baseline data (after the acclimatization period), each dog had a 22G cephalic catheter placed for drug administration. Subsequently, animals received IV administration of 
ACP in doses according to each experimental treatment $\left(0.05\right.$ or $\left.0.1 \mathrm{mg} \mathrm{kg}^{-1}\right)$. The final volume of ACP was corrected to a standardized volume of $1 \mathrm{~mL}$ with saline solution $(\mathrm{NaCl} 0.9 \%)$ and administered over 1 minute. Twenty minutes after ACP administration, the aforementioned variables were recorded (time point ACP). Thereafter, the dogs received IV administration of an opioid according to the experimental treatments. The final volume of each opioid was corrected to a standardized volume of $5 \mathrm{~mL}$, with saline solution, and administered over 5 minutes. Cardiorespiratory variables, NDS, SNS and rectal temperature were assessed again at 15-minute intervals for 120 minutes after opioid administration.

Differences among treatments in HR, SAP, $f_{\mathrm{R}}$, temperature and SNS were analyzed by a 2-way repeated measures ANOVA followed by the Bonferroni correction for multiple pairwise comparisons. A 1-way repeated measures ANOVA followed by a Dunnett's test was used to detect differences between each time point and baseline values. Differences among treatments and over time in values of NDS were compared by a Friedman and Dunn's test. For all analyses, values of $P<0.05$ were considered significant.

\section{RESULTS}

Compared with baseline values, ACP administration significantly decreased SAP in all treatments and $f_{\mathrm{R}}$ decreased in all treatments except ACPMOR. Rectal temperature was lower than baseline in all treatments except $\mathrm{ACP}_{\mathrm{HD}} \mathrm{MOR}$. Heart rate did not change significantly after ACP administration (time point ACP - Figure 1).

Mild to moderate sedation was observed after administration of ACP. Sedation scores (medians

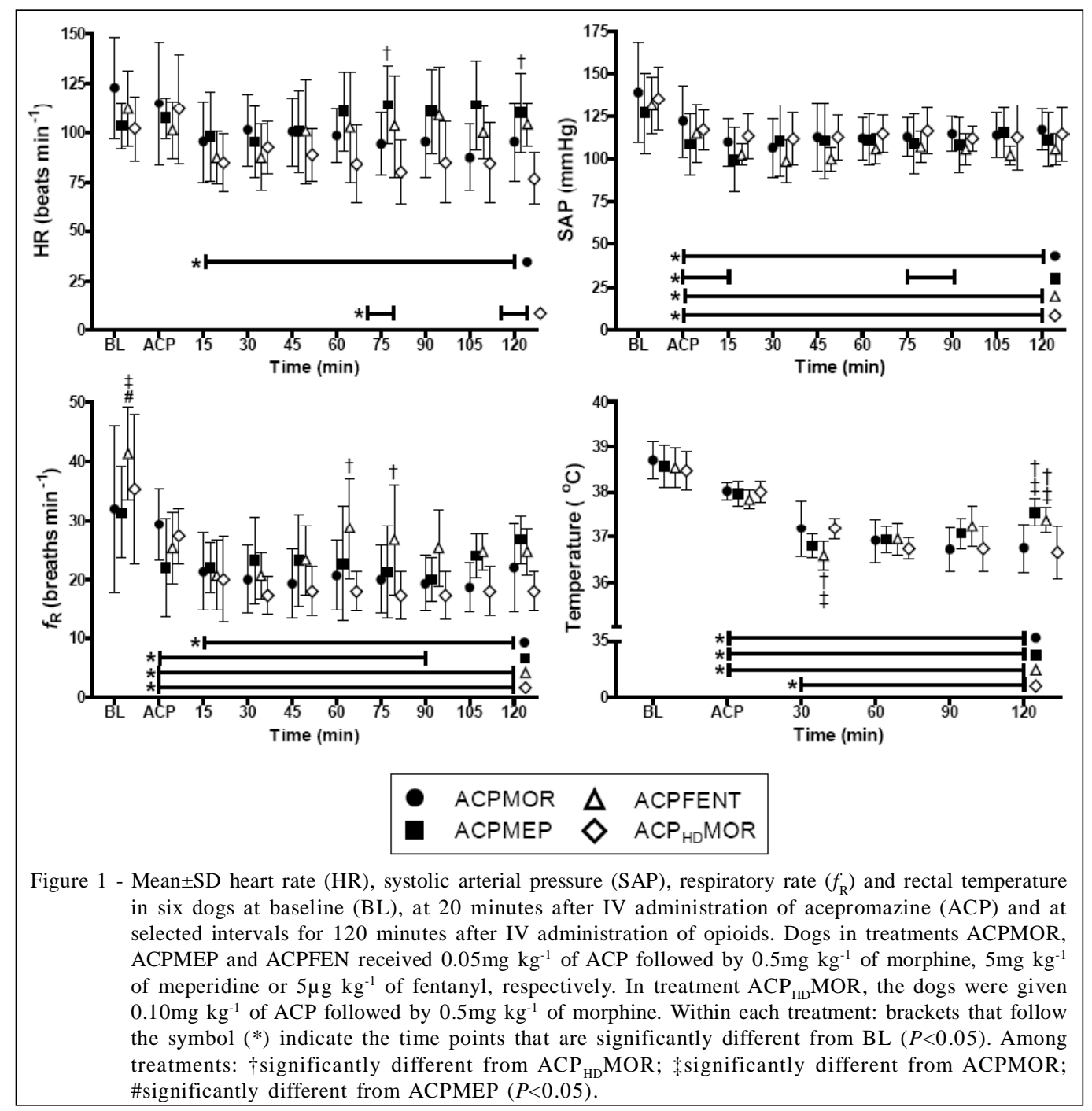

Ciência Rural, v.41, n.8, ago, 2011. 
of NDS) recorded at time point ACP were 1.0 in ACPMOR and $\mathrm{ACP}_{\mathrm{HD}} \mathrm{MOR}$ and 2.0 in treatments ACPMEP and ACPFEN. At the same time point, mean scores of SNS were 3.3, 4.3, 5.2 and 3.5 in ACPMOR, ACPMEP, ACPFEN and $\mathrm{ACP}{ }_{\mathrm{HD}} \mathrm{MOR}$, respectively (time point ACP - Figure 2).

After administration of the opioid, HR decreased significantly compared with baseline in treatments $\mathrm{ACPMOR}$ and $\mathrm{ACP}_{\mathrm{HD}} \mathrm{MOR}$ but not in the other treatments. In addition, HR was lower in $\mathrm{ACP}_{\mathrm{HD}} \mathrm{MOR}$ than in ACPMEP at 75 and 120 minutes (Figure 1). Bradycardia $\left(\mathrm{HR}<70\right.$ beats $\mathrm{min}^{-1}$ ) was observed in 2/6, 0/6, 1/6 and 3/6 dogs in treatments ACPMOR, ACPMEP, ACPFEN and $\mathrm{ACP}{ }_{\mathrm{HD}} \mathrm{MOR}$, respectively. After administration of the opioid, SAP decreased further in ACPMOR, ACPFEN and $\mathrm{ACP}_{\mathrm{HD}} \mathrm{MOR}$ treatments and values remained below baseline throughout the experimental period. In ACPMEP, SAP decreased within 15 minutes after administration of meperidine, but at 30 minutes SAP returned to values before opioid administration (Figure 1). Hypotension (SAP $<90 \mathrm{mmHg}$ ) was observed in 0/6, 2/6, 1/6 and 1/6 dogs in ACPMOR, ACPMEP, ACPFEN and $\mathrm{ACP}_{\mathrm{HD}} \mathrm{MOR}$, respectively.

Values of $f_{\mathrm{R}}$ remained below baseline during most of the observation period in all treatments. Rectal temperature decreased by 1.5 to $2.0^{\circ} \mathrm{C}$ in all treatments during the study. However, temperature returned faster to baseline values in treatments ACPMEP and ACPFEN than in other treatments (Figure 1).

Sedation was improved after administration of the opioid in all treatments, but significant differences compared with time point ACP were observed only in treatments ACPMOR and $\mathrm{ACP}_{\mathrm{HD}} \mathrm{MOR}$. Peak sedative effect appeared to occur within 15 minutes of opioid administration in treatments ACPMEP and ACPFEN whereas in ACPMOR and $\mathrm{ACP}_{\mathrm{HD}} \mathrm{MOR}$, peak sedative effect occurred between 15 and 30 minutes. Sedation scores decreased immediately after peak sedative effect in ACPMEP and ACPFEN; in ACPMOR and $\mathrm{ACP}_{\mathrm{HD}} \mathrm{MOR}$ sedation was maintained for longer periods. Scores of the NDS were higher from 30 to 60 minutes in ACPMOR than at time point ACP; similar scores during the same period were observed in $\mathrm{ACP}_{\mathrm{HD}} \mathrm{MOR}$ but the difference was not significant in comparison to time point ACP. Intense sedation (NDS scores $=3.0$ ) was observed in 3/6, 1/6, 1/ 6 and 4/6 dogs in treatments ACPMOR, ACPMEP, ACPFEN and $\mathrm{ACP}_{\mathrm{HD}} \mathrm{MOR}$, respectively.

Scores of the SNS showed a similar trend in sedation to NDS scores. Compared with time point ACP, significantly higher SNS scores were observed in treatments ACPMOR (from 15-60 minutes) and $\mathrm{ACP}_{\mathrm{HD}} \mathrm{MOR}$ (from 15-90 minutes).

\section{DISCUSSION}

The results of this investigation agree with previous studies that ACP-opioid combinations enhance the degree of sedation provided by $\mathrm{ACP}$ alone (MONTEIRO et al., 2008; MONTEIRO et al., 2009). According to this study, sedation was similar or slightly greater, and duration of this effect was longer, when

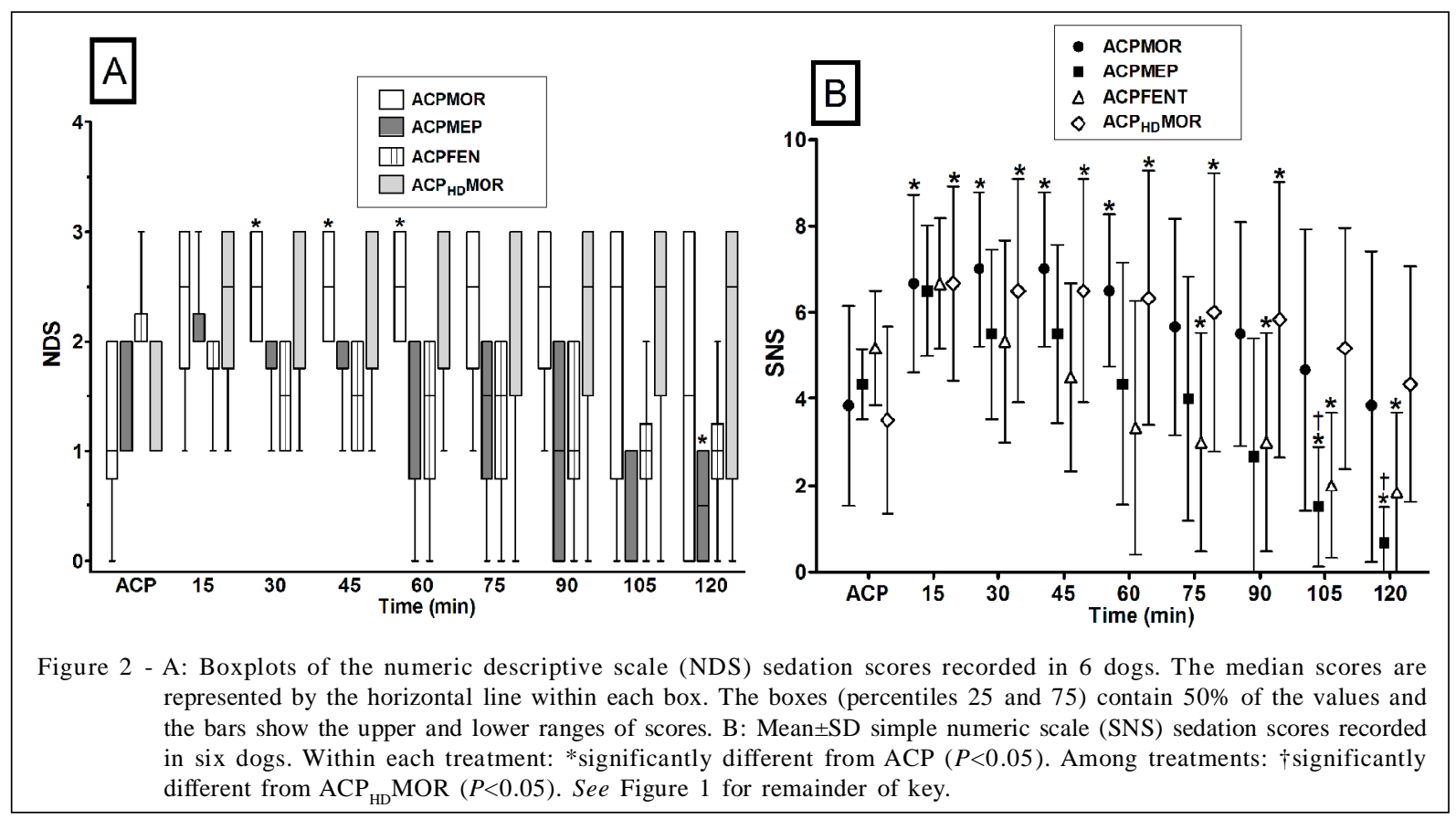

Ciência Rural, v.41, n.8, ago, 2011. 
ACP was administered in combination with morphine than with meperidine or fentanyl. Adverse effects with all combinations were similar. Sedation was not improved when doubling the dose of ACP (from 0.05 to $\left.0.10 \mathrm{mg} \mathrm{kg}^{-1}\right)$ in combination with the same dose of morphine $\left(0.5 \mathrm{mg} \mathrm{kg}^{-1}\right)$.

It has been reported in the literature that there is a ceiling effect on sedation provided by the administration of ACP because the dose-response curve rapidly reaches a plateau, which means that further increases after a certain dose does not enhance the degree of sedation (HALL et al., 2001). However, the dose-response curve of clinically used doses of ACP has not been established yet. In a previous study, it was reported that the combination of $0.05 \mathrm{mg} \mathrm{kg}^{-1}$ of $\mathrm{ACP}$ with methadone resulted in greater sedation than $0.10 \mathrm{mg} \mathrm{kg}^{-1}$ of ACPalone (MONTEIRO et al., 2008). To the authors' knowledge, no studies comparing the use of different doses of ACP, in combination with opioids, have been performed. The present study showed that doubling the dose of ACP (from 0.05 to $0.10 \mathrm{mg} \mathrm{kg}^{-1}$ ), in combination with the same dose of morphine $(0.5 \mathrm{mg}$ $\mathrm{kg}^{-1}$ ), did not improve the degree of sedation.

The combination of ACP with opioids results in greater sedation than that produced by either agent alone (SMITH et al., 2001; MONTEIRO et al., 2008). However, the degree of sedation may vary according to the opioid used in the combination (MONTEIRO et al., 2009). Several factors can interfere with the degree of sedation provided by each opioid such as selectivity for opioid receptors, pharmacokinetic differences, individual response of each animal and the method used for evaluating the degree of sedation (MONTEIRO et al., 2009). To minimize the influence of these factors on the results of this study, the doses of each opioid were considered to be equipotent, all drugs were administered intravenously, the same dogs received each of the treatments and a single blinded observer was responsible for assessing the degree of sedation in all occasions.

According to the scoring systems used to evaluate sedation in this study, administration of morphine, but not meperidine or fentanyl, significantly increased the degree of sedation provided by ACP. Additionally, ACP-morphine combinations caused intense sedation $(\mathrm{NDS}=3.0)$ in more dogs than in the other treatments (3/6 and 4/6 dogs in ACPMOR and $\mathrm{ACP}_{\mathrm{HD}} \mathrm{MOR}$ versus $1 / 6$ dogs in other treatments). These results suggest that sedation provided by ACPmorphine combinations is greater than that obtained when the opioid used is meperidine or fentanyl. However, these results should be interpreted carefully since no significant differences among treatments were observed in sedation scores at peak sedative effect. One possible explanation for the similarity in scores at peak sedative effect may be due to all opioids used in this study were pure agonists at $\mu$ receptors (PASCOE, 2000). In a previous study (MONTEIRO et al., 2009), sedation scores obtained by the same NDS used in this study were greater in dogs that received ACP in combination with methadone and morphine ( $\mu$ agonists) compared with butorphanol (kappa agonist) and tramadol (agonist with low affinity for $\mu$ receptors). The most important difference observed among the treatments in the present study was the duration of sedation, which was longer in dogs given morphine than in other treatments. According to the SNS, sedation scores returned to values observed at time point ACP within 60 minutes and 30 minutes after meperidine and fentanyl administration, respectively. These results suggest that the duration of sedative effect is similar to the analgesic effect as meperidine and fentanyl are known to cause analgesia of short duration (PASCOE, 2000).

The adverse effects observed in this study were considered to be of mild to moderate intensity and are characteristic and similar to those reported in previous studies after administration of ACP-opioid combinations (SMITH et al., 2001; MONTEIRO et al., 2008; MONTEIRO et al., 2009). The duration, but not the severity of adverse effects, appeared to be greater in dogs given morphine than in other treatments. The main adverse effects observed in the cardiovascular system were decreased HR and blood pressure. The reduction in $\mathrm{HR}$ is thought to result from increased vagal tone by opioids (HALL et al., 2001; WAGNER, 2002) whereas the reduction in SAP may have resulted from the effects of both the opioid and ACP. Phenothiazines cause a reduction in systemic vascular resistance (SVR) due to competitive antagonism at vascular alpha-1 adrenergic receptors, an effect that lasts for at least 4 hours (MONTEIRO et al., 2007). Additionally, the opioid-induced reduction in HR may have contributed to the reduction in SAP via a reduction in cardiac output $(\mathrm{CO})$ according to the equation: blood pressure $=\mathrm{CO} \times \mathrm{SVR}$ (CUNNINGHAM, 2002).

In a previous study, it was reported that the effect of ACP on blood pressure of dogs was doserelated (LUDDERS et al., 1983). However, in the present study, similar values of SAP were observed in dogs given the lower (ACPMOR) and higher $\left(\mathrm{ACP}_{\mathrm{HD}} \mathrm{MOR}\right)$ doses of acepromazine. One possible explanation for the discrepancies between the two studies is that in the previous study, dogs were anesthetized with 
halothane whereas in this study, the dogs were in the conscious state.

In all treatments in this study, there was a decrease in $f_{\mathrm{R}}$. Although ACP is known to decrease $f_{\mathrm{R}}$, tidal volume is expected to increase and minute volume is usually unchanged (HALL et al., 2001). The administration of opioids may cause respiratory depression by inhibiting the ventilatory response to hypercapnia (WAGNER, 2002). However, in dogs, the respiratory depression caused by opioids does not seem to be a concern in healthy animals unless these drugs are administered in combination with injectable or inhalational anesthetics (WAGNER, 2002). Results of the present investigation agree with previous authors who did not report the occurrence of respiratory depression, cyanosis or apnea after administration of ACP-opioid combinations (SMITH et al., 2001; MONTEIRO et al., 2008; MONTEIRO et al., 2009).

\section{CONCLUSION}

The results of the present study indicate that the combination of ACP with morphine, meperidine and fentanyl results in moderate to intense sedation, with a higher incidence of intense sedation and longer duration of effect being observed when morphine is used. The combination of morphine is indicated when intense and prolonged sedation is required whereas meperidine or fentanyl are better options for short term sedation. Results of this study do not support the use of ACP in doses higher than $0.05 \mathrm{mg} \mathrm{kg}^{-1}$, in combination with morphine, to enhance sedation.

\section{SOURCES AND MANUFACTURERS}

a - Doppler Vascular DV 10 PASTILHA; Microem Produtos Médicos.

b - Acepran 0,2\%; Univet, São Paulo, SP, Brasil.

c - Dimorf; Cristália, Itapira, SP, Brasil.

d - Dolosal; Cristália, Itapira, SP, Brasil.

e - Fentanest; Cristália, Itapira, SP, Brasil.

\section{ANIMAL CARE AND ETHICS COMMITTEE}

The present study was approved by the Institutional Animal Care and Ethics Committee (protocol: 008061).

\section{REFERENCES}

CUNNINGHAM, J.G. Circulações sistêmica e pulmonar. In: Tratado de fisiologia veterinária. 2.ed. Rio de

Janeiro: Guanabara Koogan, 2002. Cap.21, p.135-142.

HALL, L.W. et al. Principles of sedation, analgesia and premedication. In: HALL, L.W. et al. Veterinary anaesthesia. London: Saunders, 2001. Cap.4, p.75-112.

LUDDERS, J.W. et al. Blood pressure response to phenylephrine infusion in halothane-anesthetized dogs given acetylpromazine maleate. American Journal of Veterinary Research, v.44, n.6, p.996-999, Jun, 1983.

MONTEIRO, E.R. et al. Effects of acepromazine on the cardiovascular actions of dopamine in anesthetized dogs. Veterinary Anaesthesia and Analgesia, v.34, n.5, p.312321, Sep, 2007. Avaiable from: <http://onlinelibrary.wiley.com/ doi/10.1111/j.1467-2995.2006.00328. x/abstract>. Accessed: Jan. 27, 2011. doi: 10.1111/j.1467-2995.2006.00328.x.

MONTEIRO, E.R. et al. Effects of methadone, alone or in combination with acepromazine or xylazine, on sedation and physiologic values in dogs. Veterinary Anaesthesia and Analgesia, v.35, n.6, p.519-527, Nov, 2008. Avaiable from: <http://onlinelibrary.wiley.com/doi/10.1111/j.14672995.2008.00412.x/abstract>. Accessed: Jan. 27, 2011. doi: 10.1111/ j.1467-2995.2008.00412.x.

MONTEIRO, E.R. et al. Comparative study on the sedative effects of morphine, methadone, butorphanol or tramadol, in combination with acepromazine in dogs. Veterinary Anaesthesia and Analgesia, v.36, n.1, p.25-33, Jan, 2009. Avaiable from: <http://onlinelibrary.wiley.com/doi/ 10.1111/ j.1467-2995.2008.00424.x/abstract>. Accessed: Jan. 27, 2011. doi: $10.1111 / \mathrm{j} .1467-2995.2008 .00424 . x$.

PASCOE, P.J. Opioid analgesics. Veterinary Clinics of North America Small Animals Practice, v.30, n.4, p.757-772, Jul, 2000.

SMITH, L.J. et al. Effects of hydromorphone or oxymorphone, with or without acepromazine, on preanesthetic sedation, physiologic values, and histamine release in dogs. Journal of the American Veterinary Medical Association, v.218, n.4, p.1101-1105, Apr, 2001.

WAGNER, A.E. Opioids. In: GAYNOR, J.S.; MUIR, W.W. Handbook of veterinary pain management. St Louis: Mosby, 2002. Cap.9, p.164-183. 